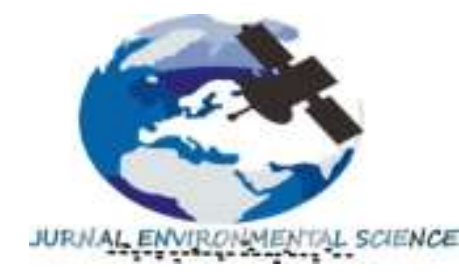

Jurnal Environmental Science

Volume 4 Nomor 1 Oktober 2021

p-ISSN : 2654-4490 dan e-ISSN : 2654-9085

Homepage at : ojs.unm.ac.id/JES

E-mail:jes@unm.ac.id

\title{
PERSEPSI DAN STRATEGI SEKTOR PERTANIAN DALAM MENGHADAPI RISIKO PERUBAHAN IKLIM : STUDI KOMPARASI PULAU ARANG (BANGLADESH) DAN SEMARANG (INDONESIA)
}

\author{
Eva Nurrahmi Lukman, Mangapul Parlindungan Tambunan², Raldi Hendro Toro \\ Seputro Koestoer ${ }^{3}$. \\ ${ }^{12}$ Program Studi Ilmu Geografi, Fakultas Matematika dan Ilmu Pengetahuan Alam, \\ ${ }^{3}$ Program Studi Ilmu Lingkungan, Fakultas Matematika dan Ilmu Pengetahuan Alam, \\ Universitas Indonesia \\ Email:eva.nurrahmi@ui.ac.id
}

\begin{abstract}
Climate change is a serious environmental problem that cannot be avoided due to global warming. This is because the impacts of climate change have been felt in every aspect of human life, one of which is the agricultural sector. Agriculture is the sector that is experiencing the most serious impact due to climate change because the agricultural sector relies on the water and weather cycle to maintain its productivity. Humans alone cannot control climate behavior. Arang Island in Bangladesh and Semarang district, Indonesia are faced with the threat of climate change risks in agriculture. The purpose of this paper is to review and compare the risks of climate change in the two regions with descriptive methods and to examine how the strategies of the two regions in dealing with climate change. The analysis shows that the people of the charcoal islands in Bangladesh applied several adaptation strategies in agriculture such as implementing new or alternative agricultural practices, changing planting times, and cultivating short-duration varieties. And farmers in Semarang district can change cropping patterns or shift planting times according to the arrival of the rainy season to reduce the risk of crop failure.
\end{abstract}

Keywords: climate change, agriculture, Semarang, Arang island Bangladesh

\begin{abstract}
ABSTRAK
Climate change (perubahan iklim) merupakan masalah serius terhadap lingkungan yang tidak dapat dihindari akibat pemanasan global. Hal ini disebabkan karena dampak perubahan iklim tersebut sudah sangat dirasakan pada setiap aspek-aspek kehidupan manusia salah satunya sektor pertanian. Pertanian merupakan sektor yang mengalami dampak paling serius akibat perubahan iklim karena sektor pertanian bertumpu pada siklus air dan cuaca untuk menjaga produktivitasnya. Manusia sendiri tidak dapat mengendalikan perilaku iklim. Pulau Arang di Bangladesh dan kabupaten Semarang, Indonesia dihadapkan pada ancaman risiko perubahan iklim pada bidang pertanian. Tujuan tulisan ininyaitu mengulas dan membandingkan risiko perubahan iklim dikedua wilayah tersebut dengan metode deskriptif dan dikaji bagaimana strategi kedua wilayah tersebut dalam menghadapi perubahan iklim. Hasis analisis menunjukkan penduduk pulau arang di Bangladesh menerapkan beberapa strategi adaptasi dalam pertanian seperti menerapkan praktik pertanian baru atau alternatif, mengubah waktu tanam, dan membudidayakan varietas berdurasi pendek. Dan petani di kabupaten semarang dapat mengubah pola tanam maupun menggeser waktu tanam disesuaikan dengan datangnya musim penghujan guna mengurangi risiko gagal panen.
\end{abstract}

Kata Kunci: perubahan iklim, pertanian, Semarang, pulau Arang Bangladesh 


\section{PENDAHULUAN}

Perubahan iklim diartikan sebagai perubahan pola dan intensitas unsur iklim dalam periode waktu yang sangat lama. Bentuk perubahan berkaitan dengan perubahan kebiasaan cuaca atau perubahan persebaran kejadian cuaca. Tentu saja penyebab utama terjadinya perubahan iklim yaitu pemanasan global. Selain pemanasan global, aktivitas manusia juga dapat mengubah iklim bumi, seperti pembakaran bahan bakar fosil (penggunaan kendaraan bermotor yang berlebih), deforestasi, dan lain-lain.

Perubahan iklim akan berdampak kepada peningkatan tinggi permukaan air laut, meningkatnya jumlah bencana alam, pergeseran rentang geografis, dan kerusakan ekosistem. Tidak hanya akan dirasakan oleh manuisa, dampak perubahan iklim juga akan dirasakan hewan, tumbuhan, maupun mikroorganisme. Pola perubahan iklim saat ini menjadi perhatian penting bagi banyak sektor sosio-ekonomi dan sensitif iklim seperti pertanian dan produksi pangan. Sekitar 1.2 - 1,5 miliar hektar lahan global sedang dalam produksi tanaman. Namun, dengan terjadinya perubahan iklim dan pemanasan global, pencapaian target ketahanan pangan global diharapkan terus menjadi tantangan besar.

Bangladesh adalah salah satu negara yang kemungkinan besar akan menghadapi dampak perubahan iklim yang paling berat. Ini adalah Negara yang secara luas dikenal sebagai salah satu negara paling rentan terhadap iklim, secara global (Alam dkk., 2019 ; Kabir dkk., 2016 ). Namun, rumah tangga di arang 1 daerah lebih rentan terhadap perubahan iklim karena kedekatannya dengan sungai rawan banjir. Adaptasi perubahan iklim dalam konteks dimensi manusia mengacu pada proses perencanaan dan pengambilan keputusan. Tindakan yang diambil dalam suatu struktur (rumah tangga, komunitas, kelompok, wilayah, negara) untuk menangani, menangani atau memodifikasi tindakan dengan lebih baik karena beberapa kondisi yang merugikan seperti bahaya lingkungan, risiko, atau peluang.

Saat ini, konsep adaptasi perubahan iklim telah banyak digunakan dalam kajian ilmu sosial, ekologi, pertanian, dan domain ketahanan. Karena dampak perubahan iklim seringkali spesifik secara geografis, penting bahwa inisiatif adaptasi perubahan iklim skala besar yang mendukung petani kecil harus mempertimbangkan prioritas lokal dan mengintegrasikan pelajaran dari upaya adaptasi otonom yang berhasil Komunitas Riverine Char di Bangladesh menghadapi keprihatinan yang meningkat akibat perubahan iklim dan kerentanan sosio-ekonomi.

Beberapa penelitian ( Alam dkk., 2016, 2017 ; Islam dkk., 2015 ; Rahman, 2010 ; Roy dkk., 2015 ; Sarker dkk., 2020 ) telah menyelidiki hubungan antara persepsi risiko perubahan iklim, kerentanan dan adopsi teknologi atau strategi adaptasi. Mengatasi risiko pertanian dari bahaya alam di dalamnya arang daerah diperlukan untuk mengurangi kemiskinan dan kerentanan arang penghuni dan untuk mencapai swasembada pangan. Karena adaptasi bersifat spesifik lokasi, sangat penting untuk dipahami dan didokumentasikan arang petani persepsi, kerentanan, dan strategi lokal untuk menyesuaikan praktik pertanian menuju ketahanan terhadap perubahan lingkungan.

Tulisan ini mengulas dan membandingkan resiliensi perubahan iklim di Bangladesh dan Indonesia dalam upaya penanganan sektor pertanian menghadapi perubahan iklim. Kedua negara ini memiliki masalah perubahan iklim yang hampir sama. Lokasi yang diangkat dalam makalah ini adalah pulau Arang (Bangladesh) dan Semarang (Indonesia).

\section{METODOLOGI}

Metode yang digunakan dalam tulisan ini adalah yang metode deskriptif kualitatif, yaitu menggambarkan dan memberikan pemaparan serta menjelaskan tentang srtategi sektor pertanian dalam menghadapi perubahan iklim berdasarkan studi literatur dan komparasi, serta menganalisis 
dengan basis teori yang relevan. Data yang digunakan pada kajian ini merupakan data sekunder, yang diperoleh melalui studi literatur, berita online, website, dokumen dan laporan dari lembaga terkait.

Dalam konteks analisis dilakukan dengan metode meta-sintesis. Secara defenisi, meta-sintesis merupakan teknik melakukan integrasi data untuk mendapatkan teori maupun konsep baru atau tingkatan pemahaman yang lebih mendalam dan menyeluruh (Perry \&

Hammond, 2002). Analisis data juga dilakukan dengan analogi dan komparasi terhadap konsep yang merujuk pada resiliensi wilayah pertanian. Menurut Hasan (2002: 126-127) analisis komparasi atau perbandingan adalah prosedur statistik guna menguji perbedaan diantara dua kelompok data (variabel) atau lebih. Untuk kasus Indonesia, pemaparan yaitu wilayah pertanian di pulau Jawa khususnya Semarang, Jawa Tengah dan untuk Negara Bangladesh di Pulau Arang.

\section{HASIL DAN PEMBAHASAN}

\section{Hasil}

\section{A. Risiko Perubahan Iklim di Pulau Arang Bangladesh}

Telah ada beberapa penelitian yang menunjukkan bahwa penghuni pulau Arang Bangladesh sangat tinggi rentan terhadap ancaman dan ketidakpastian lingkungan (Lahiri-Dutt dan Samanta, 2007; Roy et al., 2015). Karena kerentanan mereka yang tinggi terhadap risiko lingkungan, mereka secara teratur dipengaruhi oleh berbagai jenis peristiwa iklim sebagian besar merupakan 16 peristiwa iklim yang telah Ahmed et al. (2021) analisis. Berikut table yang menunjukkan persepsi risiko perubahan iklim dari arang penghuni oleh sekitar 16 peristiwa iklim yang telah ditentukan bersama dengan skor dan nilai indeks.

\begin{tabular}{|c|c|c|c|c|c|c|c|c|}
\hline $\begin{array}{l}\text { St } \\
\text { No. }\end{array}$ & Climatic events & High Perception & Medium Perception & Low Perceptian & No Perception & CCRPS & SCCRPI & Rank \\
\hline 1 & Drought & 90 & 3 & 1 & 0 & 277 & 94.22 & 1 \\
\hline 2 & River erosion & 90 & 2 & 1 & 0 & 275 & 93.54 & 2 \\
\hline 3 & Flood & 84 & 2 & 10 & 0 & 266 & 90.48 & 3 \\
\hline 4 & Severe crop pest & 71 & 8 & 3 & 0 & 232 & 78.91 & 4 \\
\hline 5 & Outhreak of diseases & 52 & 34 & 7 & 1 & 231 & 78.57 & 5 \\
\hline 6 & Heavy fog & 64 & 11 & 12 & 2 & 226 & 76.87 & 6 \\
\hline 7 & Extreme temperature (summer) & 65 & 9 & 4 & 0 & 217 & 73.81 & 7 \\
\hline 8 & Extreme temperature (winter) & 64 & 7 & 8 & 0 & 214 & 7279 & 8 \\
\hline 9 & Outbreak of animal diseases & 42 & 32 & 10 & 2 & 200 & 68.03 & 9 \\
\hline 10 & Insect infestation & 58 & 10 & 4 & 0 & 198 & 67.35 & 10 \\
\hline 11 & Soil fertility looss & 13 & 53 & 9 & 2 & 154 & 52.38 & 11 \\
\hline 12 & Extreme rainfall (summer) & 20 & 25 & 30 & 3 & 140 & 47.62 & 12 \\
\hline 13 & Depletion of ground water & 13 & 21 & 6 & 1 & 87 & 29.59 & 13 \\
\hline 14 & Safe drinking water scarcity & 16 & 9 & 14 & 7 & 80 & 27.21 & 14 \\
\hline 15 & Arsenic contanination & 16 & 6 & 7 & 16 & 67 & 22.79 & 15 \\
\hline 16 & Fire & 3 & 3 & 10 & 20 & 25 & 8.50 & 16 \\
\hline
\end{tabular}

(Sumber. Ahmed et.al 2021)

Ahmed et al. (2021) menemukan bahwa kekeringan, erosi sungai, banjir, hama tanaman, wabah beberapa penyakit, kabut tebal dan suhu ekstrim selama musim panas dan musim dingin merupakan risiko iklim utama yang dirasakan oleh masyarakat. arang penghuni. Hasil serupa ditemukan oleh peneliti lain ( Lahiri-Dutt dan Samanta, 2007 ; Alam dkk., 2017 ; Sarker dkk., 2020 ). Faktor kerentanan untuk keterpaparan, sensitivitas dan kapasitas adaptif ditunjukkan pada gambar 2 dibawah ini. 


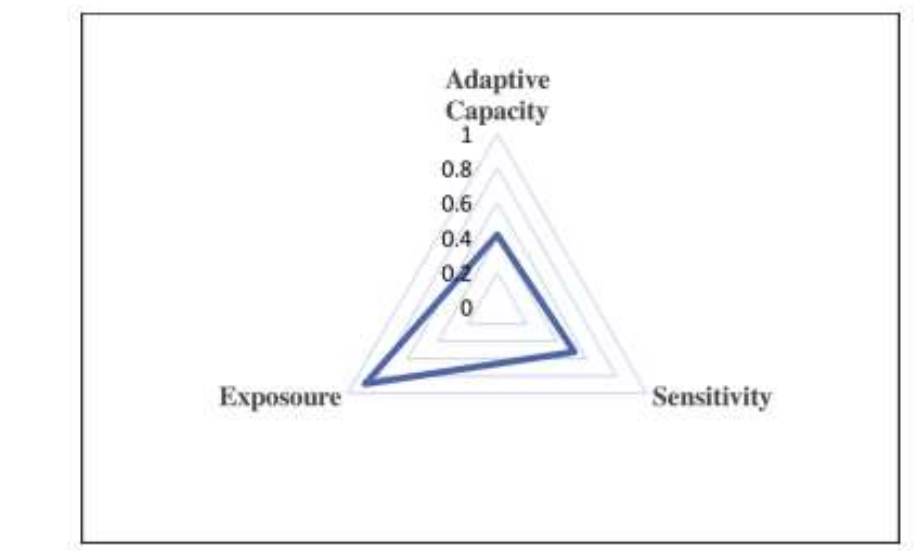

Gambar 2. Diagram segitiga kerentanan dari indeks kerentanan iklim. Sumber. Penulis 'Perhitungan s. 2020 .

(Sumber. Ahmed et.al 2021)

Berdasarkan segitiga kerentanan diatas, kita lihat kapasitas adaptif itu $(0,418)$, sensitivitas $(0,516)$ dan eksposur $(0,882)$ jelas menunjukkan kontribusi dimensi keseluruhan terhadap char kerentanan keseluruhan penghuni terhadap perubahan iklim dan lingkungan bahaya. Eksposur menyumbang kerentanan tertinggi sementara kapasitas adaptif memiliki nilai paling kecil. Dari hasil Ahmed et al. (2021) tersebut kita dapat melihat bahwa penghuni arang sering kali terkena bencana alam yang berbeda dan variabilitas iklim, dan memiliki tingkat sensitivitas yang sedang. Sebaliknya, kemampuan adaptasi mereka untuk melawan peristiwa iklim sangat rendah.

\section{B. Risiko Perubahan Iklim di Semarang Indonesia}

Sejak tahun 1990-an, berbagai kawasan di Indonesia sering dilanda kekeringan dan kebanjiran. Dampak dari kekeringan adalah gagal panen, peningkatan kematian vegetasi, dan percepatan pelapukan. Akibatnya, setiap terjadi kekeringan, ratusan hektar sawah di Pulau Jawa mengalami gagal panen atau puso (Iskandar, 2013). Dalam tabel 1 disajikan data mengenai kejadian kekeringan di Kabupaten Semarang tahun 2014.

Tabel 1. Kejadian kekeringan beserta dampaknya di Kabupaten Semarang 2014

\begin{tabular}{clcrc}
\hline No & Kecamatan & $\begin{array}{c}\text { Banyaknya desa yang } \\
\text { mengalami kekeringan }\end{array}$ & $\begin{array}{c}\text { Luas lahan pertanian yang } \\
\text { terdampak kekeringan (Ha) }\end{array}$ & Puso (Ha) \\
\hline 1 & Bringin & 11 desa & 45 & 0 \\
2 & Pringapus & 1 desa & 162 & 72 \\
3 & Susukan & 2 desa & 0 & 0 \\
4 & Jambu & 1 desa & 0 & 0 \\
5 & Suruh & 5 desa & 3 & 0 \\
6 & Tengaran & 4 desa & 0 & 0 \\
7 & Bancak & 3 desa & 55 & 0 \\
8 & Pabelan & 1 desa & 5 & 0 \\
9 & Tuntang & 3 desa & 20 & 0 \\
10 & Banyubiru & 2 desa & 46 & 0 \\
11 & Ambarawa & 3 desa & 91 & 0 \\
12 & Bandungan & 1 desa & 13 & 0 \\
13 & Bawen & 1 desa & 54 & 0 \\
14 & Ungaran Barat & 1 desa & 6 & 0 \\
\hline
\end{tabular}

Sumber: BPBD dan Dinas Pertanian Kabupaten Semarang (2015)

(Sumber. Ida Nurul et.al 2015) 
Berdasarkan tabel diatas kecamatan dari 19 kecamatan yang ada di Kabupaten Semarang mengalami kejadian kekeringan. Dalam kejadian kekeringan ini hanya 11 kecamatan yang berdampak pada lahan pertanian. Luas daerah pertanian terdampak paling parah adalah Kecamatan Pringapus yaitu sebesar $162 \mathrm{Ha}$ dan mengalami puso sebesar $72 \mathrm{Ha}$.

\section{Pembahasan}

\section{A. Presepsi Perubahan Iklim di Pulau Arang Bangladesh}

Pengukuran persepsi risiko perubahan iklim adalah suatu prosedur yang kompleks dan bergantung pada faktor sosial, budaya, ekonomi, dan demografi (Cutter dkk., 2012). Persepsi risiko yaitu konstruksi mental (Sjoberg, 2000) dan persepsi risiko perubahan iklim petani itu beragam, dalam arti tertentu yang memungkinkan untuk membedakan antara bahaya dunia nyata yang sebenarnya. Misalnya, perubahan iklim, dan evaluasi intuitif dari bahaya tersebut (Rosa, 2003; Cutter, 1996). Seperti yang kita ketahui dari data dan kejadian terkini bahwa perubahan iklim merupakan salah satu ancaman terbesar bagi kehidupan di bumi, tetapi dalam hal evaluasi tingkat individu, dalam kasus Ahmed et al. (2021) pertanian tingkat rumah tangga, kemudian persepsi risiko perubahan iklim penghuni char sangat bervariasi satu sama lai.

Telah banyak peneliti yang menggunakan teknik serupa untuk mengukur iklim mengubah persepsi risiko dari pengalaman pribadi menggunakan skala likert (Sarker et al., 2020; Akanda dan Howlader, 2015; Alam et al., 2017). Di penelitian perilaku, skala likert banyak digunakan untuk membantu peneliti dalam konstruksi skala persepsi relatif. Dalam penelitian ini, Ahmed et al. (2021) telah menggunakan jenis skala Likert yang serupa untuk mengukur persepsi risiko penghuni karakter tentang perubahan iklim. Dalam hal ini, CCRPS dan SCCRPI adalah diperhitungkan untuk memperoleh pemahaman yang lebih baik tentang bagaimana penghuni char mempersepsikan risiko yang terkait dengan perubahan iklim.

Ahmed et al. (2021) menghitung CCRPS pada 16 peristiwa iklim yang berkisar antara 25 hingga 277 (nilai terendah 0 hingga nilai tertinggi 294). Setelah menganalisis kisaran nilai CCRPS, Ahmed et al. (2021) tidak mengetahui apakah Penghuni arang rata-rata sensitif terhadap risiko perubahan iklim, sebaliknya kita dapat mengatakan bahwa penghuni char memiliki tingkat rendah sampai sedang sensitivitas untuk empat peristiwa iklim terakhir (nilai 25 hingga nilai 87) dan tingkat sensitivitas sedang hingga tinggi untuk sisa peristiwa iklim (nilai 140 sampai nilai 277). Namun, dari SCCRPI, kita dapat melihat bahwa file nilai bervariasi secara substansial mulai dari 8,50 hingga 94,22 yang menggambarkan bahwa kategori persepsi penghuni char itu heterogen. Namun, Sebagian besar penghuni char tergolong dalam indeks persepsi sedang hingga tinggi nilai (47.62-94.22) dan kurang termasuk persepsi rendah dan sedang nilai indeks (8,50-29,59). Dari diskusi kelompok terarah, Ahmed et al. (2021) menemukan yang cocok dengan nilai indeks yang peneliti hitung untuk setiap peristiwa iklim tanggapan kumulatif penghuni char..

Bangladesh adalah negara yang dianggap sangat rentan terhadap efek merugikan dari perubahan iklim (Alam et al., 2019; Mahmood, 2012; Abdur dkk., 2013; Kementerian Lingkungan Hidup, Hutan dan Perubahan Iklim, 2009). Kecenderungan yang tinggi dari Bangladesh terhadap perubahan iklim telah dipengaruhi oleh kedekatan geografisnya dengan pegunungan Himalaya, sumber sungai dan rumah bagi gletser yang terancam iklim; itu datar topografi delta dengan ketinggian yang sangat rendah; kepadatan populasinya dan terjadinya kemiskinan; dan ketergantungan mayoritas penduduknya pada pertanian tanaman yang dipengaruhi iklim secara komprehensif (Bank Dunia, 2013) 
Masyarakat pulau Arang Bangladesh mengalami berbagai jenis iklim bahaya seperti kekeringan, banjir, sungai, erosi, dll. Dan persepsi mereka tentang kerentanan bervariasi dari kapasitas adaptif rendah hingga keterpaparan tinggi. Musim Kharif (Mei hingga Oktober) adalah musim tanam utama di Bangladesh. Karena kesulitan menyediakan yang diperlukan irigasi ke ladang tanaman, tekstur tanah berpasir dan penguapan tinggi, paling banyak petani arang menjaga tanah mereka tetap kosong selama musim Kharif. Sebagai gantinya, petani arang terutama mengolah tanah mereka selama musim Rabi (November hingga April) saat suhu lebih rendah dan tanah-air kapasitas retensi lebih menguntungkan untuk budidaya. Selain itu, persepsi dan kerentanan perubahan iklim rumah tangga juga didukung berdasarkan data iklim yang diamati (Gambar 3 dan 4)

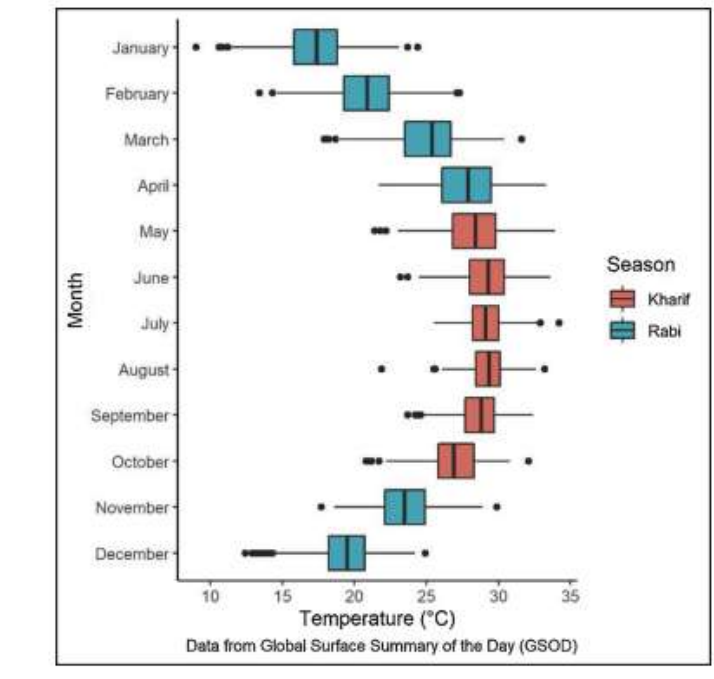

Gambar 3. Pola suhu historis Gaibandha (1990 hingga 2020). Sumber. Penulis ' Perhitungan menggunakan data GSOD.

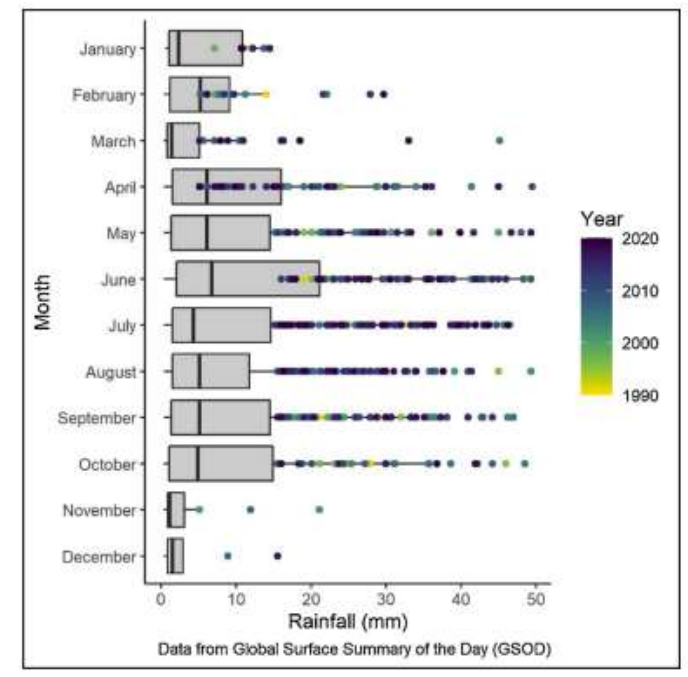

Gambar 4. Pola curah hujan historis Gaibancha (1990 hingga 2020). Sumber. Penules. 'Perhilungan menggunakan data GSOD.

(Sumber. Ahmed et.al 2021)

Para masyarakat telah mengadopsi lebih dari satu strategi untuk mengamankan mata pencaharian mereka, sebuah proses yang dikenal sebagai ketahanan mata pencaharian. Selain itu, penghuni char kebanyakan mempraktikkan dua jenis adaptasi, Individual Level Adaptation (ILA) dan Planned Adaptation (PA) (Alam et al., 2017). ILA tidak selalu merupakan respons terhadap perubahan iklim secara langsung tetapi merupakan respons langsung terhadap perubahan iklim dipicu oleh perubahan ekologi, ekonomi, dan kesejahteraan yang ada sistem manusia, yang merupakan hasil adaptasi pribadi, dimulai dan dilaksanakan oleh individu atau rumah tangga.

\section{B. Presepsi Perubahan Iklim di Semarang Indonesia.}

Indonesia merupakan negara pertanian yang besar, di mana pertanian memegang peranan penting dari keseluruhan perekonomian nasional. Hal ini dapat ditunjukkan dari banyaknya penduduk yang hidup atau bekerja pada sektor pertanian (Mubyarto, 1989). Sektor pertanian sangat rentan terhadap perubahan iklim karena berpengaruh terhadap pola tanam, waktu tanam, produksi, dan kualitas hasil (Nurdin, 2011).

Petani di kecamatan Bringin telah mengetahui adanya perubahan pada kondisi iklim mikro di Kecamatan Bringin. Hal tersebut berdampak pada penurunan kualitas dan kuantitas hasil panen, bahkan mengalami kegagalan panen sehingga menyebabkan kerugian. Meskipun petani merasakan dampak dari perubahan iklim tersebut, namun hanya $23 \%$ petani yang mengetahui dan memahami tentang fenomena perubahan iklim tersebut. Sedangkan $71 \%$ petani hanya pernah mendengar istilah perubahan iklim dan merasakan dampaknya saja tanpa dapat menjelaskan definisi penyebabnya lebih lanjut. Hal ini menunjukkan rendahnya tingkat pengetahuan petani mengenai isu perubahan iklim 
yang sedang terjadi saat ini. Seluruh petani menyatakan bahwa mereka mendapatkan informasi tentang perubahan iklim dari media telivisi, radio, dan sesama petani.

Pada awalnya, masyarakat terbiasa memperkirakan musim melalui pengeahuan yang umum digunakan masyarakat. Sebanyak $100 \%$ petani memprediksi musim hujan dimulai setiap bulan Oktober sampai Mei dan kemarau dari bulan Juni sampai september. Seluruh petani mengatakan bahwa telah terjadi pergeseran musim yang menyebabkan sulitnya memprediksi awal atau akhir dari musim hujan ataupun musim kemarau. Dampak dari perubahan iklim ini menurut petani menyebabkan semakin panjang nya musim kemarau. Musim kemarau cenderung tiba pada bulan Juni hingga November. Pergeseran musim memberikan dampak terhadap peningkatan risiko gagal panen, kerusakan hasil panen, dan penurunan kualitas panen

Petani menyadari perubahan iklim dan dampaknya terhadap produksi tanaman pangan telah mampu mengembangkan strategi mata pencaharian, serta adaptasi yang mereka lakukan dengan cara yang terus menerus bisa dilakukan untuk mengatasi dampak perubahan iklim yang tidak menentu terhadap produksi tanaman pangan (Ayunwuy, dkk., 2010). Soejono dkk. (2009) menyatakan bahwa faktor-faktor yang signifikan terhadap produksi adalah pupuk, obat-obatan dan tenaga kerja. Sedangkan faktor yang tidak signifikan berpengaruh terhadap produksi adalah luas lahan dan benih.

\section{SIMPULAN}

Penelitian Ahmed et al. (2021) menunjukkan bahwa kekeringan, erosi sungai, dan banjir merupakan risiko iklim utama dirasakan oleh penghuni pulau Arang Bangladesh. Selain itu, hasil dari indeks kerentanan iklim menggambarkan temuan serupa. Responden lebih terpapar pada bahaya iklim yang beragam. Studi lebih lanjut menyelidiki adaptasi local mekanisme di bidang pertanian sehubungan dengan peristiwa iklim utama. Menanggapi risiko perubahan iklim yang ada, Ahmed et al. (2021) menjelaskan bahwa masyarakat menerapkan beberapa strategi adaptasi di bidang pertanian seperti penerapan baru atau alternative praktik bertani, mengubah waktu tanam, dan membudidayakan varietas berdurasi pendek.

Analisis llogit didalam paper ini menyarankan bahwa usia rumah tangga, ukuran keluarga, pendapatan tahunan, luas lahan, kepemilikan lahan dan pengalaman bertani memiliki pengaruh yang signifikan terhadap pilihan adaptasi petani. Akses rumah tangga ke pendidikan, peringatan dini dengan penyuluhan agen, informasi tentang teknologi pertanian yang ditingkatkan, akses ke sumber pendapatan di luar pertanian, dan menggabungkan orang-orang char selama desain kebijakan dapat secara efektif meningkatkan ketahanan petani dan membantu mengurangi kerentanan.

Perubahan iklim yang digambarkan dengan keadaan kekeringan mempunyai pengaruh yang signifikan pada tingkat kepercayaan 5\%. Lahan yang teridentifikasi sebagai lahan rawan kekeringan di Semarang berpotensi menurunkan produksi pertanian. Pemerintah diharapkan dapat membantu pengembangan usaha tani padi, misalnya memperlancar sistem pendistribusian pupuk agar tidak terciptanya kelangkaan pupuk dan juga mengadakan lembaga simpan pinjam dan pengenalan asuransi pertanian yang dapat meringankan petani dalam masalah pengadaan modal usaha tani dan kerugian finansial sebagai dampak perubahan iklim. Petani yang tinggal di daerah rawan kekeringan harus meningkatkan strategi adaptasi yang dilakukan untuk mengurangi dampak kerugian akibat perubahan iklim. Petani dapat mengubah pola tanam maupun menggeser waktu tanam disesuaikan dengan datangnya musim penghujan guna mengurangi risiko gagal panen. 


\section{DAFTAR PUSTAKA}

Abdur, R.S., Alam, K., Gow, J., 2013. Assessing the determinants of rice farmers' adaptationstrategies to climate change in Bangladesh. Int. J. Clim. Chang. Strateg. Manage. 5 (4), 382-403. https://doi.org/10.1108/IJCCSM-06-2012-0033

Alam, G.M.M., Alam, K., Mushtaq, S., 2017. Climate change perceptions and local adaptation strategies of hazard-prone rural households in Bangladesh. Clim. Risk Manag. 17, 52-63. https://doi.org/10.1016/j.crm.2017.06.00

Akanda, M.G.R., Howlader, M.S., 2015. Coastal farmers' perception of climate change effects on agriculture at Galachipa Upazila under Patuakhali District of Bangladesh. Global J. Sci. Front. Res. Agric. Vet. 15, 31-39.

Aldrian, dkk. (2011). Adaptasi dan Mitigasi Perubahan Iklim di Indonesia (PDF). Jakarta: Pusat Perubahan Iklim dan Kualitas Udara, Kedeputian Bidang Klimatologi, Badan Meteorologi, Klimatologi, dan Geofisika. hlm. 39.

Cutter, L.S., 1996. Vulnerability to environmental hazards. Prog. Hum. Geogr. 20 (4), 529-539. https://doi.org/10.1177/030913259602000407.

Hindarto, dkk. (2018). \#pasarkarbon: Pengantar Pasar Karbon untuk Pengendalian Perubahan Iklim. Jakarta Pusat: PMR Indonesia. hlm. 8.

Indah N urul Hidayati, Suryanto 2015, Peengaruh Perubahan Iklim Terhadap Produksi Pertanian dan Strategi Adaptasi Pada Lahan Rawan Kekeringan. Vol. 16, hlm.42-52

Islam, M., Sultana, S., Saifunnahar, M., Miah, M., 2015. Adaptation of char livelihood in flood and river erosion areas through indigenous practice: a study on Bhuapur riverine area in Tangail. J. Environ. Sci. Nat. Resour. 7 (1), 13-19. https://doi.org/ 10.3329/jesnr.v7i1.22138.

Kabir, R., Khan, H.T.A., Ball, E., Caldwell, K., 2016. Climate change impact: the experience of the coastal areas of Bangladesh affected by cyclones Sidr and Aila

Mahmood, S.A.I., 2012. Impact of climate change in Bangladesh: the role of public administration and government's integrity. J. Ecology Nat. Environ. 4 (8), 223-240. https://doi.org/10.5897/JENE11.088.

Mubyarto. (1989). Pengantar Ekonomi Pertanian. Jakarta: LP3ES

Nurdin. (2011). Antisipasi perubahan iklim untuk keberlanjutan ketahanan pangan. Sulawesi Utara: Universitas Negeri Gorontalo.

Rahman, M.R., 2010. Impact of riverbank erosion hazard in the Jamuna floodplain areas in Bangladesh. J. Sci. Found. 8 (1\&2), 55-65. Retrieved from. https://pdfs.semant icscholar.org/88f8/33a8d99cc5f74da3029c2b5db86465464458.pdf.

Rosa, E.A., 2003. The logical structure of the social amplification of risk framework (SARF): metatheoretical foundations and policy implications. In: Pidgeon, N.F., Kasperson, R.E., Slovic, P. (Eds.), The Social Amplification of Risk. Cambridge University Press, Cambridge, pp. 47-79. Retrieved from. https://trove.nla.gov.au/work/28268203.

Roy, B., Ullah, M., Rahman, M., 2015. Climate change impact in Char lands in central area of Bangladesh: assessing vulnerability and adaptation by the farming communities. J. Environ. Sci. Nat. Resour. 7 (2), 59-63. https://doi.org/10.3329/ jesnr.v7i2.22205

Sarker, M.N.I., Wu, M., Alam, G.M.M., Shouse, R.C., 2020. Life in riverine islands in Bangladesh: local adaptation strategies of climate vulnerable riverine island dwellers for livelihood resilience. Land Use Policy 94, 1-7. https://doi.org/10.1016/j. landusepol.2020.104574

Sjoberg, ". L., 2000. The methodology of risk perception research. Qual. Quant. 34 (4), $407-418$. https://doi.org/10.1023/A:1004838806793 